\title{
Obstacles to achieve competitive advantage in Arab schools in Israel in light of contemporary attitudes and methods to achieve it from the viewpoint of their teachers
}

\author{
Prof. Linda Fuad Safoury
}

\begin{abstract}
This study aimed at evaluating obstacles to achieve competitive advantage in Arab schools in Israel in light of contemporary attitudes and methods to achieve it from the viewpoint of their teachers. To achieve the study objective; the researcher used the qualitative method and an interview. The study population consisted of all school teachers who work in Arab area in Israel, and a sample consisted of (31) teachers were chosen in arbitrary method, during the first academic semester 2020/2021. The study findings showed the existence of obstacles that prevent the achievement of a competitive advantage for Arab schools in Israel, the most important were: the failure to provide an integrated database for all members of the school community, and the scarcity of teacher training programs developed according to modern technical developments. In addition, the most important methods to achieve a competitive advantage for Arab schools in Israel were: communicating with educational experts, Providing everyone with the opportunity of training, and Linking career development to improving performance
\end{abstract}

Key words: Obstacles, competitive advantage, contemporary attitudes.

DOI: $10.7176 / \mathrm{EJBM} / 13-6-22$

Publication date:March 31st 2021

\subsection{Introduction}

Firms achieve a competitive advantage when they produce a product or service that meets customer needs at a lower price, when they offer differentiating features not provided by competitors, or when they meet the needs of customers not served readily by their competitors. Resources need not be in the form of better raw materials but may also be tacit, such as the presence of an established relationship or the developed capabilities of an unusual team or individual. In today's knowledge-based economy, the use of specialized knowledge and information is often the source of competitive advantage. The nature of competitive advantages is that they are rarely permanent, although the exclusive ownership of a technology or the possession of a patent can extend the life of an advantage (Caldwell, 2017).

El-Sherbiny, (1984) pointed out that the important source in building competitive advantages is the volume and amount of competition in improving the outputs and capabilities available to competitors, as increasing the volume of competition definitely leads to the organization's interest in strategic aspects such as strategic planning for its operations and activities, including marketing in order to stand up to competitors. And distinguishing them by having characteristics that are not available to others that enable the organization to provide the product of value to the customers to obtain through it their satisfaction and approval, while the organization gains a good reputation and expands its market share at the expense of other competitors.

The concept of competitiveness at the level of the organization means the ability to provide the consumer or the customer with more efficient and effective products and services than other competitors in the local and international market. Competitiveness is measured through the growth rates of the organization and its ability to achieve a greater share in the market. As for the concept of competitiveness at the level of a specific industrial sector, it means the ability of companies in a specific sector in a country to achieve continuous success in international markets without relying on support and protection from the government, and thus the distinction of that state in this industry (Salman, 2005). The Organization for Economic Cooperation and Development (OCDE) defined competitive advantage as "competitiveness in the degree to which a country, in light of free global trade and market conditions, can produce goods and services that meet the choices and needs of international markets, while preserving - at the same time - the real income of its individuals and increasing it. The long-term". This understanding emerges from the point of view that competitiveness is embedded in the type of economic system that the state adopts (Abdel-Aal, 2017).

The competitive advantage is represented by the distinct skills, techniques and resources that allow the 
organization to produce benefits for customers that exceed what competitors offer them (Al-Selami, 2009). Various organizations seek to achieve competitive advantage by enhancing the organization's sensitivity to the requirements of the times, by developing the speed of response to customer needs, improving the product, and demonstrating efficiency and quality in processes and outputs, at low costs compared to competing organizations (Egger \& Hristova, 2018). Al-Melehi (2012) also explained that the factor of product differentiation and cost reduction is one of the most important factors in achieving a competitive advantage by developing the organization's ability to design, manufacture, and market a product at a lower cost compared to competing organizations and ultimately lead to greater returns. It requires providing a distinct, unique and valuable product from the customer's point of view, so it becomes necessary to understand the potential sources of service differentiation and employ the capabilities and competencies of the organization to achieve aspects of excellence.

Increasingly, competitive advantage has begun to identify the importance of innovation as the critical component of creating that advantage. Firms that reconfigure the nature of competition by creating a product or service that is cheaper but that contains fewer capabilities than their competitors can sometimes create a totally new market space that attracts customers that previously had not been able to afford the product or service. Oxford Advanced Learners Dictionary Online defined competitive advantage as expressing something that helps an organization to be better or more successful than others, and of a quality that makes everything better or more beneficial, and it is a description of a situation in which people or organizations compete against each other, or try Striving to be a better institution than others.

Competitive advantage relates to a situation in which people or groups try to win a competition or are more successful than others, and it may express a strong desire to win or be the best at something. The competitive advantage is the institution's ability to formulate and implement strategies that make it in a better position relative to other institutions operating in the same activity (Al-Tayyib, 2007). The competitive advantage includes the dimensions in which the corporation can compete with others in a more effective way, and it represents a point of strength that characterizes the institution without its competitors in one of its production, service, or marketing activities, or in relation to its human resources or geographical location (Al-Hawajza, 2010).

(Al-Ghamdi, 2014; Al-Madhoun, 1999; Abu Ghaben, 2012; Al-Dhafiri, 2019; Al-Issawi, 2018; Dammaj, 2019) explained that achieving competitive advantage in schools requires the adoption of a set of policies, as follows:

1. Urging the application of the principles of intellectual capital management in Arab schools to provide quality outputs capable of improving education.

2. Raising the level and effectiveness of teachers 'performance in Arab schools, in order to provide quality products.

3. Promote research and discovery that includes indicators related to teachers and the diversity of schools and their programs.

4. Overcoming administrative deficiencies in community institutions, with the aim of improving the quality of outputs.

5. Keeping pace with global changes in terms of achieving management requirements, to improve the outputs.

6. Strengthening the affiliation with educational institutions, by following systematic incentive programs, to motivate workers to give their best.

7. Attention to workers and the pursuit of developing their skills and capabilities, which is reflected in the quality of high-quality products capable of achieving a competitive advantage.

8. Development of work methods, in general and in all its parts, and in all institutions of society, so that the quality of the outputs for that country would be high quality, following the example of the character and quality of Japanese educational products.

9. The introduction of modern management methods and all institutions to achieve the highest levels of accuracy and distinctive quality.

10. Developing awareness of the concept of intellectual capital management, due to its importance in investing minds and achieving competitive advantage in Arab societies, especially as it includes educated and distinguished human competencies capable of providing competitive products.

11. Paying attention to teachers' competencies, in order to achieve for them the ability to provide distinguished outputs, commensurate with their needs and the needs of the labor market in future periods of time.

12. Preparing a culture among teachers in all schools that qualifies them to live through the times with its ups and 
downs, to be able to compete, and to provide quality and uniqueness products that achieve competitive advantage.

13. Adopting an educational principle (producing a qualified director only).

14. Empowering teachers, by giving them the opportunity to think, analyze, and discover errors and methods needed to address them.

15. Preparing strategic and operational plans in line with levels of scientific knowledge and technical developments in all fields, based on scientific studies and applied research on developing knowledge contents and skill levels and developing performance techniques, to achieve high-quality outputs.

The importance of the competitive advantage is that it is the basic basis on which the performance of organizations is based, and studies and research during the past few years of the twenty-first century are not devoid of the concept of competitive advantage. The emergence of this concept and its dominance over various trends made it important for organizations as one of the options that the organization uses to adapt And adaptation to the requirements of competition and change. The competitive advantage is practically aimed at meeting the needs and desires of the beneficiaries, and the importance of the competitive advantage of educational institutions can be summarized as follows (Khalil, 2017):

- The competitive advantage is a positive indication of the educational institution's tendency to occupy a strong position among its competitors. Competitive advantage is an essential factor in the work of schools and universities of all kinds.

- The competitive advantage is important by being considered a basic competitive weapon to meet the challenges of competitive educational institutions.

- Competitive advantage is an important criterion for identifying successful educational institutions.

- The importance of competitive advantage in improving the level of strategic leadership.

The most important obstacles to achieve competitive advantage are (Radwan, 2020):

- The rigidity of regulations and regulations.

- Lack of financial resources.

- Lack of delegation of powers.

- Lack of clarity of evaluation criteria.

- Poor utilization of available technologies.

- The educational institutions become accustomed to centralizing management.

- Community customs and traditions, and the lack of realistic institutional evaluation and performance evaluation of the two employees.

- Poor ability to employ technology, lack of support from senior management.

- The resistance of workers to a variable in the various stages of the administrative process.

As Akbar (2017) showed that the most important principles needed to achieve competitive advantage in schools are:

- Supporting distinguished behavior and confirming the competitive advantage by reducing the number of regulations and laws restricting the distinguished performance, in addition to self-respect and mutual trust between the manager and his employees.

- The development of human resources through various methods of delegating authority, recognition of the efforts exerted aimed at achieving competitive advantage and updating and developing the capabilities of workers.

- Clarifying the goals and objectives of the school as it is the foundation upon which the distinguished organization is based, taking into account defining its vision and mission in the future.

- Providing the changing and developing socio-economic environment in which educational institutions operate.

- Creating effective administrative leadership with its pivotal role in directing the educational institution towards innovative, advanced thinking and creating the appropriate climate for achievement.

- Determine planning, preparation and coordination of relations with the surrounding climate and investment of material and financial resources.

- Available to achieve the goals and objectives of the school.

- The application of strategic management, which is the administrative methodology that is based on investing available opportunities, avoiding threats, and achieving the organization's mission and goal. 
- The School of Excellence is committed to applying the comprehensive quality approach in order to achieve the beneficiary's satisfaction from the educational service, and to establish its competitive position in the community.

- Activating comprehensive management information systems for developing knowledge and investing it through directing operations and achieve intellectual and administrative excellence and support competitive capabilities.

- The necessity of forming human resources in educational institutions from the category of workers with knowledge, competence and experience.

- The necessity of continuous development and improvement by management in educational institutions.

It is evident from the foregoing the importance of achieving a competitive advantage in schools because of its great importance in improving students' learning and providing them with the skills necessary for life, but there are many obstacles that limit the achievement of competitive advantage in schools, which requires identifying these obstacles and proposing appropriate ways to achieve the advantage. Competition, based on the current study, to identify obstacles to achieving competitive advantage in Arab schools in Israel in light of contemporary trends and ways to achieve competitive advantage.

\subsection{Study problem and questions}

Schools are the first educational institution responsible for preparing the future generation, providing them with all the skills needed to work, build society, coexist with others, and develop their ability to solve problems, creativity and innovation. That to reach meaningful learning, which requires keeping pace with modern developments, especially in the field of technology, and making use of them in developing students' skills. There is no doubt that the school plays an important role in the upbringing and education of students. Moreover, instill in them the ability to learn, develop and compete, which helps to prepare successful individuals who can enter the field of working with a serious spirit and can participate effectively in the creation, improvement and refinement of its outputs for competition and excellence. Competitiveness in the field of school education requires the development and improvement of educational programs with international characteristics and standards. This provide learners with specialized and multiple skills and techniques, as well as the productive flexibility advocated by the labor market, and this requires the preparation of educational programs based on technology and the knowledge economy, and thus achieving the school's competitive advantage has become more important. Introduction to developing competitiveness in education, and this requires the development of specialized educational and training programs. Hence, there is an urgent need to review the educational and educational systems in order to reformulate their goals and improve their performance according to the entrance to the competitive advantage of the school. Based on the results of many previous studies which confirmed the importance of achieving competitive advantage in school education, such as the study of Yassin (2017) and Eid (2018) And Khawaldeh (2020), Ababneh (2020), Muhammad (2020), Al-Ajami (2020), Radwan (2020), Salah alDin (2018), Dammaj (2014), Masoud (2015), Othman (2017), Akbar (2017) Al-Issawi (2018), Al-Dhafiri (2019), Ahmed (2018), the need to conduct the current study was confirmed, with the aim of investigating the obstacles to achieving competitive advantage in schools in light of contemporary attitudes and methods to achieve them. Therefore, the current study problem was to identify obstacles to achieve competitive advantage in Arab schools in Israel in light of contemporary attitudes and methods to achieve competitive advantage from the point of view of their teachers, and more clearly, the study problem was represented by answering the following two subquestions:

The first question: What are the obstacles of achieving competitive advantage in Arab schools in Israel in light of contemporary attitudes from the point of view of their teachers?

The second question: What are the methods to achieve competitive advantage in Arab schools in Israel in light of contemporary attitudes from the point of view of their teachers?

\subsection{The aims of the study}

The study aims to achieve two main objectives, linked to the study questions, by collecting and analyzing data:

- Identifying the obstacles to achieving competitive advantage in Arab schools in Israel in light of contemporary attitudes from the point of view of their teachers.

- Investigating methods to achieve competitive advantage in Arab schools in Israel in light of contemporary attitudes from the point of view of their teachers.

\subsection{Importance of the study}

The importance of this study emerged from the urgent need to identify the obstacles to achieve competitive advantage in Arab schools in Israel in light of contemporary attitudes and methods to achieve it from the viewpoint 
of their teachers. Because of the rapid technical, social and educational changes in Israel, so the importance of this study comes from its results, and the impact of these results on those in charge of decision maker in Israel, and the importance of this study can be shown as follow:

\section{Theoretical importance:}

- Enrich the theoretical aspect regarded the Obstacles to achieve competitive advantage in Arab schools in Israel in light of contemporary attitudes and methods to achieve it, as the researcher hopes that the study results contribute in enriching Israel library in this field.

- This study is expected to open up new doors in the field of Obstacles to achieve competitive advantage in Arab schools in Israel in light of contemporary attitudes and methods to achieve it from the viewpoint of their teachers, to conduct new studies to promote or deny the findings of this study.

\section{Applied practical aspect:}

- It hoped to benefit from the findings and recommendations of this study in providing a feedback to principals about the obstacles to achieve competitive advantage in schools in the light of contemporary attitudes and methods to achieve it.

- It hoped to benefit from the findings and recommendations of this study the researchers and those interested in obstacles to achieve competitive advantage in light of contemporary attitudes and methods to achieve it.

- It hoped that this study finding help educational decision-makers in Israel in identifying the obstacles to achieve competitive advantage in Arab schools in Israel in light of contemporary attitudes and methods to achieve it from the viewpoint of their teachers, to help them in making appropriate decisions to improve the education.

\subsection{Terminology}

The study adopting identifying the following terms:

Competitive advantage: the competitive advantage is defined as: "the organization's means to discover new methods that are more effective than those used by competitors, as it is able to embody this discovery in the field" (Porter, 2016).

\subsection{Study limitations}

The results of this study are determined by the nature of the sample and the tool of the study, as follows:

- The sample: it is limited to in Arab schools teachers.

- The temporal boundary: it is limited to the academic year 2020-2021.

- Objective limit: Obstacles to achieve competitive advantage in Arab schools in Israel in light of contemporary attitudes and methods to achieve it from the viewpoint of their teachers.

\subsection{Variables}

The study includes two dependent variables, namely:

- The obstacles of achieving competitive advantage in Arab schools in Israel in light of contemporary attitudes from the point of view of their teachers.

- The methods to achieve competitive advantage in Arab schools in Israel in light of contemporary attitudes from the point of view of their teachers.

\section{Previous studies}

The current study adopted the presentation of a set of previous studies that were addressed from the most recent to the oldest, as follows:

AlKhawaldeh (2020) conducted a study aimed at investigating the reality of competitive advantage in secondary government schools in Al- Mafraq Governorate. The survey method and the questionnaire were used. The study sample consisting of (153) principals, the study results showed that the reality of competitive advantage in secondary government schools in Al- Mafraq Governorate from the point of view of the study sample individuals got a total average score (2.73 out of 5). The field of leadership got the highest average; (2.90 out of 5) followed by the field of human resources management with an average of (2.73) and thirdly, the field of quality, with an average of (2.65) and finally the field of technology with an average of (2.62), all of which are verbal (average). Furthermore, there were no statistically significant differences attributed to gender variable; on the overall level 
of the tool and on all fields. Based on the results of the study, the researcher presented a set of recommendations and proposals, the need to keep abreast of what is new to develop school performance in the light of competitive advantage.

Ababneh (2020) conducted a study aimed at identifying the reality of the competitive advantage in public secondary schools in the State of Kuwait, from school principals' point of view. To achieve the objective of this study, the researchers have developed a questionnaire which consisted of (44) items, its validity and reliability were confirmed, and distributed to (190) male and female principals. The researchers depended on the descriptive survey methodology. Results of the study showed that the degree of evaluation reality of the competitive advantage in public secondary schools in the State of Kuwait from the point of view of the respondents came at medium degree. In addition, results showed the absence of differences with statistically significance in the study sample individuals evaluation of reality of the competitive advantage in public secondary schools in the State of Kuwait attributed to gender at the total level of the instrument and on all dimensions. In light of the results, the researchers recommended a set of recommendations.

The study of Muhammad (2020) showed that the challenges facing contemporary educational institutions that threaten their existence, potential, and the quality of their outputs have resulted from the emergence of alternative educational institutions that use modern techniques and deal with the concepts of globalization and knowledge economy. Therefore, the study seeks to monitor competitiveness indicators in education and identify factors that can contribute to building the competitive advantage of educational institutions, as many educational institutionsespecially primary schools- are still unable to achieve a competitive advantage that preserves their survival and ensures their continuity. Although these educational institutions have sought to ensure a good, comprehensive and equitable education, this goal is still elusive because of a host of constraints that hinder educational institutions to achieve a competitive advantage or introduce a good educational service. The study used the descriptive approach to analyze competitiveness indicators in education, and to explain the different sources of competitive advantage and their building factors in primary schools. The study concluded that primary schools could build a competitive advantage when they are able to exploit all their human, financial, technological and cognitive resources to increase their efficiency in providing high quality education and deliver a good learning output. Innovation and continuous improvement in the educational service help to have a competitive advantage that other schools do not possess. Finally, the study proposed a series of measures that could help primary schools achieve a competitive advantage that ensures their survival and continuity.

Al-Ajmi (2020) conducted a study aimed at identifying the reality of competitive advantage in public secondary schools in the State of Kuwait, from school principals' point of view. To achieve the objective of this study, the researchers have developed a questionnaire which consisted of (44) items, its validity and reliability were confirmed, and distributed to (190) male and female principals. The researchers depended on the descriptive survey methodology. Results of the study showed that the degree of evaluation reality of the competitive advantage in public secondary schools in the State of Kuwait from the point of view of the respondents came at medium degree. Also, results showed the absence of differences with statistically significance in the study sample individuals evaluation of reality of the competitive advantage in public secondary schools in the State of Kuwait attributed to gender at the total level of the instrument and on all dimensions.

Radwan study (2020) aimed to identify leadership skills as an entry point to achieve competitive advantage in pre-university education institutions. The study depends on descriptive methodology which analyses the reality and explain it scientifically and logically and take this problem accurately by collecting accurate data about the phenomenon and analyzing it. The research reached at some mechanisms to active: Leadership skills in achieving competitive advantage in pre-university education institutions such as: spreading a culture of development among managers of general secondary schools. Holding training courses and programs in leader ship skills field. School leaders are chosen on the basis of the availability of skills (self, administrative, human, artistic, intellectual, administrative or pictorial). Attention to developing these skills (self-manage mental humanity-technicalintellectual-cognitive) for general secondary schools managers. Holding seminars; scientific meetings and conferences which aim at definition the importance of leader ship skills and ways of activating it.

Al-Dhafiri (2019) conducted a study aimed at determining the requirements for achieving competitiveness in schools in the State of Kuwait, by presenting the literature on the competitiveness of schools, and the descriptive and analytical approach was used. The most important requirements are: Concentration of human resources management on risks, especially as it limits the institution's ability to sustain competitive advantage. Emphasizing the importance of organizations owning scarce resources, regardless of cost because they are of utmost importance in achieving and sustaining competitive advantage. Pay attention to team work. Provide appropriate allocations for collective research projects. Promoting communication between schools at the local and Arab levels, communicate with foreign schools and conduct joint research between them. 
Al-Issawi's study (2018) aimed to present a practical and theoretical framework about "The impact of Strategic Vigilance on achieving Sustainable Competitive Advantage SWOT analysis results as a moderator". This framework was tested in a number of schools of the private education sector in Basra. The questionnaire and interviews were used as a tool of data collection for this study. The sample size was 343. A number of statistical techniques were used to test the hypotheses of the study. The results showed that the positive impact of strategic vigilance on sustainable competitive advantage, as well as demonstrated of the impact of strategic vigilance on sustainable competitive advantage.

Ahmed (2018) conducted a study aimed at revealing the effectiveness of management by roaming in achieving a competitive advantage in post-basic education in the Sultanate of Oman. The study relied on the descriptive approach. The tool of the study was a questionnaire directed at teachers to investigate their opinions about the degree of principals' practice of management by roaming in post-basic education schools. The questionnaire was distributed to 452 teachers of post-basic education schools in the Sultanate of Oman, from grades 11-12. The study found the effectiveness of management by roaming in achieving a competitive advantage in post-basic education in the Sultanate of Oman, especially associated with the use of modern technologies, continuous training, and delegation of authorities.

Salah Al-Din (2018) conducted a study aimed to suggest some procedures for activating leadership practices that support the achievement of competitive advantage in the basic education schools in the Sultanate of Oman. It seeks to identify the theoretical bases of the school leadership in order to achieve the competitive advantage in schools and explore the degree of responsiveness of school principals, assistant principals and teachers to leadership practices in support of achieving the competitive advantage in basic education schools in Muscat based on the following dimensions: distinguished human resources, better physical and financial resources, integrated and flexible organizational structure, quality of educational service provided. The study also seeks to identify the differences of opinions among the sample responses about these practices, according to demographic variables (gender, job, school type). The research was based on the descriptive approach and the use of the questionnaires administered to (9) school principals and (11) assistants and (262) teachers in basic education schools in the Muscat Governorate in Oman. The research reached a number of results, the most important of which are: The degree to which the sample responded to school leadership practices in support of competitive advantage was poor, The least practiced dimensions were the integrated and flexible organizational structure followed by the quality of educational service provided, then outstanding human resources, and finally the best material and financial resources.

Al-Eid (2018) conducted a study aimed at investigating the requirements for achieving competitive advantage in private schools in Riyadh. The research was based on the descriptive approach. The research tools was a questionnaire, and it was applied to a group of private school owners in the city of Riyadh, whose number is (468) owners. The results of the research confirmed that the members of the research sample agree to a very high degree of the importance of the technology requirements necessary to achieve competitive advantage in private schools. They also emphasized that the degree of severity of the obstacles is high, and this is attributed to the need for private education to update its administrative systems, which may suffer from stagnation and obsolescence in many regulations and systems, as well as the lack of funding for private education institutions.

Yasin (2017) conducted a study is to identify the availability degree of electronic services at secondary schools in Gaza's Governorates and its relationship to the competitive advantage from the perspective of teachers. It also aimed at unveiling the significance of differences in the average of the study sample to the availability degree of electronic services at secondary schools in Gaza's Governorates according to the study variables (gender, qualification, and years of service). To fulfill the objectives of the study, the researcher has used the descriptive analytical design using a questionnaire as a tool for data collection. The study sample consists of 400 male and female teachers who received the questionnaire. After analyzing statically the questionnaire data, the study concluded the following results: the availability degree of electronic services in secondary schools has reached from the perspective of teachers to a moderate degree and relative weight of (63.20\%). However, the level of the competitive advantage came out to a moderate degree and relative weight of $(66.40 \%)$. There are statistically significant differences between the averages of respondents' estimation degrees to the availability degree of electronic services, and the level of competitive merit at secondary schools in Gaza's provinces due to the variable gender. Nevertheless, there are no statistically significant differences found due to the variable of (qualification and years of service). There is a positive and direct correlation relationship statistically significant between electronic services provided by high schools in Gaza's provinces and its competitive advantage.

Othman (2017) conducted a study aimed at formulating a proposed model to achieve the competitive advantage of the elementary school in Egypt in light of employing the ethical leadership approach, due to its positive and critical repercussions on the development and activation of administrative processes in the primary school and on 
the student, teacher, and the educational process with its effect. Experts were surveyed about it through the application of Delphi style courses, until a near agreement was reached on the leadership practices contained in the proposed model, and the proposed model included the foundations of competitive advantage, mechanisms for achieving it in schools, and ethical leadership from the perspective of contemporary management thought literature. And the reality of employing the ethical leadership approach in elementary school in Egypt. And the leader's role in developing administrative processes and activating the components of moral leadership, as well as his role in achieving its principles, as well as his role in applying mechanisms to ensure the continuity of achieving ethical leadership practices.

Akbar (2017) conducted a study aimed at uncovering the practices of administrative leaderships to achieve competitive advantage in secondary education schools in Jeddah, Saudi Arabia. The study relied on the descriptive approach. A questionnaire was used to identify the reality of administrative leadership practices to achieve a competitive advantage in secondary education schools. The questionnaire was constructed and divided into five main dimensions. Then, they were applied to a random sample of (167) female teachers from secondary schools in Jeddah. The results of the study indicated that some principals have awareness of the importance of formulating the school's vision, mission and goals to achieve educational quality in the school. In addition, that some of the principals have the ability to make any change, development or reform that improves the educational process in the school. Moreover, that some of the principals are working to provide an opportunity for female employees in the school to participate in the quality management of the school to achieve a competitive advantage that makes it different with other schools. In addition to the need to develop human resources through delegation of authority, recognition of the efforts exerted aimed at achieving competitive advantage, and updating and developing the capabilities of workers. Moreover, clarify the goals and objectives of the school as the foundation upon which the distinguished organization is based, taking into account defining its vision and mission in the future.

Masoud (2015) conducted a study aimed at uncovering strategic features to achieve the competitive advantage of public schools in public education in Egypt. The study relied on the descriptive approach. The sample of the study consisted of 96 individuals from principals, agents and expert teachers from basic and secondary schools. The study tool was a questionnaire to collect data. The results of the study concluded that among the most important strategies that help to achieve a competitive advantage in public schools in public education are represented in the following, in descending order, the internal strategies related to human resources, the internal strategies related to the school administration, the external strategies that are achieved with the help of the ministry, the external strategies that can be achieved with the help of entities and individuals. The results also concluded with a proposed scenario to achieve the competitive advantage of public schools in public education.

Dammaj (2014) conducted a study aimed at identifying the role of strategic liveliness in achieving competitive advantage in secondary schools, Republic of Yemen, through identifying the strategic liveliness, its dimensions, the competitive advantage and its dimensions as well. The researcher has used the analytical descriptive method made use of by similar previous studies. The researcher has concluded with a number of findings, the most important of which is that strategic liveliness along with its dimensions (strategic sensitivity, collective commitment and resource liquidity) has an effective role in achieving competitive advantage in its dimensions (innovation - quality - efficiency - responding to client needs).

\section{Method and procedures}

\subsection{Methodology}

This study aimed at evaluating obstacles to achieve competitive advantage in Arab schools in Israel in light of contemporary attitudes and methods to achieve it from the viewpoint of their teachers, so the study used the qualitative method, which regarded suitable for this study.

The study population consisted of all school teachers who work in Arab area in Israel, and a sample consisted of (31) teachers were chosen in arbitrary method.

\subsection{The Study tool}

The study tool was an interview was developed by the researcher to identify obstacles to achieve competitive advantage in Arab schools in Israel in light of contemporary attitudes and methods to achieve it from the viewpoint of their teachers. Interviews were conducted using the telephone.

\subsection{Validity of the study tool}

To ascertain the validity of the study tool, content validity was used by viewing the questionnaire to (9) arbitrators of the faculty members who specialize in educational administration, so as to take their opinions on the content of the tool, and the adequacy of paragraphs, and the need to modify or delete any questions, and any 
comment they think it is necessary, in the light of the observations of the arbitrators, some questions were modified, but no question deleted, and the researcher found that the questions were correlated to their aims of the study, as the agreement degree between the arbitrators reached $(90 \%)$, and this percentage is regarded suitable for the purposes of this study.

\subsection{Reliability of the study tool}

Research tool reliability was assured reliability by using the (Test- retest), and by applying it on (15) school teachers from outside the research sample, and Pearson correlation coefficient was calculated, and the value of reliability coefficient was (0.78), and this is an acceptable value for the purposes of the Research.

The obstacles to achieve competitive advantage in Arab schools in Israel in light of contemporary attitudes and methods to achieve it from the viewpoint of their teachers were determined by analyzing and classifying the answers of the study sample, collecting similar ones, and arranging them according to their frequency from top to bottom, so that the most important statement is in the first rank, followed by the least important phrase in the second rank, and then the least important is in the third, and so on.

\subsection{Statistical treatment}

To answer the questions of the study the appropriate statistical methods were used as follow:

- To answer the first, second question, the duplicates were counted.

\section{Study results and discussion}

Findings of the study and its discussion: The study presents the findings that reached through the respondents of the sample to their questions, as follows:

The findings of the first study question: What are the obstacles of achieving competitive advantage in Arab schools in Israel in light of contemporary attitudes from the point of view of their teachers?

After collecting and analyzing the data obtained from the members of the study sample who were interviewed, about the obstacles of achieving competitive advantage in Arab schools in Israel, in light of contemporary attitudes from the point of view of their teachers. These obstacles were arranged in descending order according to their frequency in the responses of the study sample who were interviewed; the most important obstacles came in descending order as follow:

Table (1): Frequencies and ranks of obstacles to achieving competitive advantage in Arab schools in Israel in light of contemporary trends from the point of view of their teachers

\begin{tabular}{|r|l|c|c|}
\hline no. & \multicolumn{1}{|c|}{ The question } & The duplicates & rank \\
\hline 1 & $\begin{array}{l}\text { Failure to provide an electronic system for exchanging information } \\
\text { about the school's workflow. }\end{array}$ & 31 & 1 \\
\hline 20 & $\begin{array}{l}\text { Failure to provide an integrated database for all members of the school } \\
\text { community. }\end{array}$ & 31 & 1 \\
\hline 11 & $\begin{array}{l}\text { The scarcity of teacher training programs developed according to } \\
\text { modern technological developments. }\end{array}$ & 31 & 1 \\
\hline 10 & $\begin{array}{l}\text { Poor training of administrative staff according to modern plans and } \\
\text { programs. }\end{array}$ & 30 & 4 \\
\hline 16 & Insufficient communication with educational experts. & 30 & 4 \\
\hline 13 & Lack of training opportunities for everyone. & 30 & 4 \\
\hline
\end{tabular}




\begin{tabular}{|c|c|c|c|}
\hline 9 & Not choosing teachers on clear grounds. & 30 & 4 \\
\hline 21 & $\begin{array}{l}\text { Weak educational environment that encourages commitment to quality } \\
\text { and excellence standards. }\end{array}$ & 29 & 8 \\
\hline 48 & Lack of financial resources needed to develop educational plans. & 29 & 8 \\
\hline 27 & $\begin{array}{l}\text { Weak work on educating administrative staff about the importance of } \\
\text { change. }\end{array}$ & 29 & 8 \\
\hline 36 & $\begin{array}{l}\text { Lack of work to educate members of the school community about the } \\
\text { importance of development. }\end{array}$ & 29 & 8 \\
\hline 35 & $\begin{array}{l}\text { Weak support of planning programs specialized in developing } \\
\text { educational activities. }\end{array}$ & 29 & 8 \\
\hline 43 & Not to follow the plans of advanced educational systems. & 28 & 13 \\
\hline 45 & $\begin{array}{l}\text { Failure to benefit from the educational policies of advanced } \\
\text { educational systems. }\end{array}$ & 28 & 13 \\
\hline 37 & $\begin{array}{l}\text { There is a deficiency in providing modern technologies that keep pace } \\
\text { with the era of modernity. }\end{array}$ & 28 & 13 \\
\hline 44 & -There is a lack of continuous electronic communication methods. & 28 & 13 \\
\hline 22 & $\begin{array}{l}\text { Deficiencies in providing the material requirements for program } \\
\text { planning and implementation. }\end{array}$ & 28 & 13 \\
\hline 42 & Poor access of school community members to information resources. & 28 & 13 \\
\hline 46 & $\begin{array}{l}\text { Poor training of educational personnel in generating and exchanging } \\
\text { knowledge. }\end{array}$ & 27 & 19 \\
\hline 23 & Failure to continuously measure and monitor teachers 'performance. & 27 & 19 \\
\hline 26 & $\begin{array}{l}\text { The lack of indicators to measure performance according to clear } \\
\text { criteria. }\end{array}$ & 27 & 19 \\
\hline 30 & Insufficient motivation for all employees. & 27 & 19 \\
\hline 18 & Lack of financial motivation for all employees. & 26 & 23 \\
\hline 8 & Not linking career development to improving performance. & 26 & 23 \\
\hline 17 & $\begin{array}{l}\text { Weak revision of training programs according to contemporary } \\
\text { developments. }\end{array}$ & 26 & 23 \\
\hline 15 & Weak focus on quality standards in developing the Arab school. & 26 & 23 \\
\hline 4 & There is a deficiency in fully or partially computerizing the curriculum. & 26 & 23 \\
\hline 5 & Failure to benefit from the expertise of advanced educational systems. & 25 & 28 \\
\hline 12 & $\begin{array}{l}\text { Lack of awareness of the need for continuous training for } \\
\text { administrative and educational cadres. }\end{array}$ & 25 & 28 \\
\hline
\end{tabular}




\begin{tabular}{|c|c|c|c|}
\hline 2 & $\begin{array}{l}\text { Weakness of the necessary measures to motivate educational and } \\
\text { administrative staff to self-learn. }\end{array}$ & 25 & 28 \\
\hline 14 & $\begin{array}{l}\text { Not to involve the community in solving the problems of the Arab } \\
\text { school. }\end{array}$ & 24 & 31 \\
\hline 19 & $\begin{array}{l}\text { Weak provision of the necessary financial support to achieve teacher } \\
\text { satisfaction. }\end{array}$ & 24 & 31 \\
\hline 3 & Lack of professional development of teachers. & 24 & 31 \\
\hline 34 & $\begin{array}{l}\text { The lack of flexibility necessary to amend laws, regulations and } \\
\text { instructions in accordance with educational developments. }\end{array}$ & 24 & 31 \\
\hline 38 & $\begin{array}{l}\text { The lack of flexibility necessary to amend laws, regulations and } \\
\text { instructions according to technical developments. }\end{array}$ & 24 & 31 \\
\hline 33 & $\begin{array}{l}\text { The lack of flexibility necessary to amend laws, regulations and } \\
\text { instructions according to the development of educational psychology. }\end{array}$ & 23 & 36 \\
\hline 7 & $\begin{array}{l}\text { Weak curriculum planning and development in accordance with the } \\
\text { principles of modern curricula. }\end{array}$ & 23 & 36 \\
\hline 6 & Weak community involvement in improving the quality of education. & 23 & 36 \\
\hline 29 & $\begin{array}{l}\text { Failure to involve the community in improving the educational } \\
\text { process. }\end{array}$ & 23 & 36 \\
\hline 41 & Weak empowerment of teachers to practice administrative work. & 23 & 36 \\
\hline 47 & $\begin{array}{l}\text { Weak adoption by the administration of finding more than one way to } \\
\text { implement operations. }\end{array}$ & 23 & 36 \\
\hline 25 & $\begin{array}{l}\text {-The lack of adoption by the administration of the process of rotating } \\
\text { teachers to acquire new and various skills. }\end{array}$ & 22 & 42 \\
\hline 32 & -Poor operational cost control. & 22 & 42 \\
\hline 40 & $\begin{array}{l}\text { The failure of management to encourage employees to compete and } \\
\text { develop. }\end{array}$ & 21 & 44 \\
\hline 39 & The failure of management to encourage employees to be creative. & 21 & 44 \\
\hline 31 & Weakness of directing employees to compete with others. & 20 & 46 \\
\hline 28 & The educational system's poor consideration of teachers' needs. & 20 & 46 \\
\hline 24 & $\begin{array}{l}\text { Insufficient sensitivity of the educational system to technical } \\
\text { development. }\end{array}$ & 20 & 46 \\
\hline
\end{tabular}

It is noticed from Table (1) that there are (48) paragraphs confirming the existence of obstacles that prevent the achievement of a competitive advantage for Arab schools in Israel from the teachers 'point of view. , Paragraph (2) which states "the failure to provide an integrated database for all members of the school community," and Paragraph (11) which states "the scarcity of teacher training programs developed according to modern technical developments" has obtained a consensus of the study sample as the most important obstacles to achieving competitive advantage in Arab schools; It got (31) recurrences. 
It is also noted that Paragraph (31), which stipulated "the weakness of directing the administration working to compete with others," Paragraph (28), which stipulated "the weakness of the educational system's consideration of teachers's needs," and Paragraph (24), which stipulated "insufficient sensitivity of the educational system The technical development has obtained the lowest frequency, as the number of iterations reached (20) iterations, and this is an indication of the importance of these obstacles.

This result may be attributed to the prevailing routine of administration in Arab schools, to the extreme centralization of administration, to the lack of delegation of powers, the lack of inclination towards selfmanagement of the school, and the association of all schools with a strict educational law that does not allow the school to choose its curricula, build, or expand construction. Or, providing an electronic system or an integrated database for all members of the school community, and the prevailing education system does not provide new teacher training programs according to modern technical developments, in addition to poor training of administrative cadres according to modern plans and programs, lack of communication with educational experts, and the lack of material resources Necessary to develop educational plans. The weakness of work to educate the administrative cadres of the importance of change, the weakness of work to educate members of the school community of the importance of development, the weakness of support for planning programs specialized in the development of educational activities, the failure to follow the plans of advanced educational systems, the lack of benefit from the educational policies of the advanced educational systems; This is all due to the lack of a clear organized plan that allows competition among practitioners to achieve a competitive advantage.

The result of the current study is similar to many of the results of previous studies that showed the existence of various obstacles to achieving a competitive advantage in educational institutions such as the results of Yassin (2017), Eid (2018), Khawaldeh (2020), Ababneh (2020), Muhammad (2020), Al-Ajami (2020), Radwan (2020), Salah al-Din (2018), Dammaj (2014), Masoud (2015), Othman (2017), Akbar (2017), Al-Issawi (2018), Al-Dhafiri (2019), Ahmed (2018).

The findings of the second study question: What are the ways to achieve competitive advantage in Arab schools in Israel in light of contemporary attitudes from the point of view of their teachers?

After collecting and analyzing the data obtained from the members of the study sample who were interviewed, about the obstacles to achieving competitive advantage in Arab schools in Israel in light of contemporary trends from the point of view of their teachers the most important methods were proposed to address these obstacles, which are the means of development and they were arranged in descending order as follow:

Table (1): Frequencies and ranks of ways to achieve competitive advantage in Arab schools in Israel in light of contemporary trends from the point of view of their teachers

\begin{tabular}{|r|l|c|c|}
\hline no. & \multicolumn{1}{|c|}{ The question } & The duplicates & rank \\
\hline 5 & Communicate with educational experts. & 31 & 1 \\
\hline 6 & Providing everyone with the opportunity of training. & 31 & 1 \\
\hline 24 & Linking career development to improving performance. & 31 & 1 \\
\hline 25 & $\begin{array}{l}\text { Conducting a review of training programs according to contemporary } \\
\text { developments. }\end{array}$ & 31 \\
\hline 26 & Focusing on quality standards in developing the Arab school. & 31 & 1 \\
\hline 37 & Community involvement in improving the quality of education. & 31 & 1 \\
\hline 4 & $\begin{array}{l}\text { Administrative personnel are trained according to modern plans and } \\
\text { programs. }\end{array}$ & 30 \\
\hline
\end{tabular}




\begin{tabular}{|c|c|c|c|}
\hline 7 & - Selecting teachers based on clear foundations. & 30 & 7 \\
\hline 8 & $\begin{array}{l}\text { Providing an encouraging educational environment towards adherence } \\
\text { to quality and excellence standards. }\end{array}$ & 30 & 7 \\
\hline 21 & Setting indicators to measure performance according to clear criteria. & 30 & 7 \\
\hline 22 & Motivating all employees morally. & 30 & 7 \\
\hline 23 & Motivate all employees financially. & 30 & 7 \\
\hline 36 & $\begin{array}{l}\text { Curriculum planning and development according to the principles of } \\
\text { modern curricula. }\end{array}$ & 30 & 7 \\
\hline 46 & - The administration directs workers to compete with others. & 30 & 7 \\
\hline 3 & $\begin{array}{l}\text { Creating teacher-training programs in accordance with modern } \\
\text { technological developments. }\end{array}$ & 29 & 15 \\
\hline 11 & Educating the school community about the importance of development. & 29 & 15 \\
\hline 13 & - following the plans of the advanced educational systems. & 29 & 15 \\
\hline 18 & $\begin{array}{l}\text { Facilitating the school community members' access to information } \\
\text { resources. }\end{array}$ & 29 & 15 \\
\hline 20 & Continuous measurement and monitoring of teachers' performance. & 29 & 15 \\
\hline 29 & Continuous training for administrative and educational staff. & 29 & 15 \\
\hline 35 & $\begin{array}{l}\text { Amending laws, regulations and instructions according to the } \\
\text { development of educational psychology. }\end{array}$ & 29 & 15 \\
\hline 45 & Encouraging the management of employees to be creative. & 29 & 15 \\
\hline 1 & $\begin{array}{l}\text { Providing an electronic system for exchanging information about the } \\
\text { school's workflow. }\end{array}$ & 28 & 23 \\
\hline 9 & Providing the necessary material resources to develop educational plans. & 28 & 23 \\
\hline 12 & $\begin{array}{l}\text { - Supporting the planning of programs specialized in developing } \\
\text { educational activities. }\end{array}$ & 28 & 23 \\
\hline 19 & Training of educational personnel to generate and exchange knowledge. & 28 & 23 \\
\hline 30 & Motivating the educational and administrative cadres to self-learning. & 28 & 23 \\
\hline 40 & Empowering teachers to focus on self-learning. & 28 & 23 \\
\hline 41 & $\begin{array}{l}\text { The administration adopts finding more than one method to implement } \\
\text { operations. }\end{array}$ & 28 & 23 \\
\hline 48 & $\begin{array}{l}\text { The educational system actively takes into account technical } \\
\text { development. }\end{array}$ & 28 & 23 \\
\hline 2 & Providing an integrated database for all members of the school & 27 & 31 \\
\hline
\end{tabular}




\begin{tabular}{|c|c|c|c|}
\hline & community. & & \\
\hline 10 & Educating administrative staff about the importance of change. & 27 & 31 \\
\hline 14 & $\begin{array}{l}\text { - Taking advantage of the educational policies of the advanced } \\
\text { educational systems. }\end{array}$ & 27 & 31 \\
\hline 32 & Providing the necessary material support to achieve teacher satisfaction. & 27 & 31 \\
\hline 47 & - The educational system takes into account the needs of teachers. & 27 & 31 \\
\hline 15 & Providing modern technologies that keep pace with the era of modernity. & 26 & 36 \\
\hline 31 & Community participation in solving the problems of the Arab school. & 26 & 36 \\
\hline 16 & Providing continuous electronic communication methods. & 25 & 38 \\
\hline 33 & $\begin{array}{l}\text { Amending laws, regulations and instructions according to educational } \\
\text { developments. }\end{array}$ & 25 & 38 \\
\hline 17 & $\begin{array}{l}\text { Providing the material requirements for program planning and } \\
\text { implementation. }\end{array}$ & 24 & 40 \\
\hline 34 & $\begin{array}{l}\text { Amending laws, regulations and instructions according to technical } \\
\text { developments. }\end{array}$ & 24 & 40 \\
\hline 27 & Computerizing of school curricula, in whole or in part. & 22 & 42 \\
\hline 38 & Community participation in improving the educational process. & 22 & 42 \\
\hline 28 & - To benefit from the experiences of advanced educational systems. & 21 & 44 \\
\hline 39 & Empowering teachers to work to practice administrative work. & 19 & 45 \\
\hline 42 & $\begin{array}{l}\text { The administration adopts the process of rotating teachers to acquire new } \\
\text { and varied skills. }\end{array}$ & 19 & 45 \\
\hline 43 & Reducing operational costs. & 19 & 45 \\
\hline 44 & Encouraging management for employees to compete and develop. & 19 & 45 \\
\hline
\end{tabular}

It is noticed from Table (1) that there are (48) paragraphs indicating methods to achieve a competitive advantage for Arab schools in Israel from the teachers 'point of view. It is noticed that Paragraph (5) which stipulated "Communicate with educational experts", and Paragraph (6) which stated " Providing everyone with the opportunity of training” Paragraph (24) which stated“ Linking career development to improving performance, "Paragraph (25) which stipulates" Conducting a review of training programs according to contemporary developments, "and Paragraph (26) which stated "Focusing on quality standards in developing the Arab school", and paragraph (37), which stated "Community involvement in improving the quality of education" has obtained unanimous study sample as the most important methods of achieving competitive advantage in Arab schools; It got (31) recurrences.

It is also noted that Paragraph (39) which stipulated: "Empowering teachers to work to practice administrative work", Paragraph (42), which stated "The administration adopts the process of rotating teachers to acquire new and varied skills," and Paragraph (43), which stated: "Reducing costs Operational, and Paragraph (44), which stipulates "Encouraging management for employees to compete and develop", has obtained the lowest frequency, as the number of iterations reached (19) iterations. Although these methods have obtained the lowest frequency, they are very important in achieving competitive advantage. 
these results of the current study are similar to the results of many previous studies that showed some methods to achieve a competitive advantage in educational institutions such as the results of Yassin (2017), Eid (2018), Khawaldeh (2020), Ababneh (2020), Muhammad (2020), Al-Ajami (2020), Radwan (2020), Salah al-Din (2018), Dammaj (2014), Masoud (2015), Othman (2017), Akbar (2017), Al-Issawi (2018), Al-Dhafiri (2019), Ahmed (2018) .

\section{Recommendations and suggestions}

In the light of the findings of this study, the researcher recommends the following:

- School administrations adopt to provide an electronic system for exchanging information about the school's workflow.

- School districts administrations adopt to provide an integrated database for all members of the school community.

- School districts administrations adopt to carry out teacher training programs according to modern technological developments.

- School districts administrations adopt a plan to communicate with educational experts.

- Conducting more studies applied to other societies to identify the Obstacles to achieve competitive advantage in Arab schools in Israel in light of contemporary attitudes and methods to achieve it and comparing their results with the results of the current study.

\section{References}

Abdel Aal, A. (2017), Competitive Advantages in Egyptian Universities in the Light of Strategic Intelligence, Journal of the College of Education in Educational Sciences, 40 (4), 199-219, College of Education, Ain Shams University.

Abu Ghaban, A. (2012). The role of e-learning in enhancing the competitive advantage. Islamic University of Gaza.

Ahmed, Azzam (2018), Management by roaming as an introduction to the competitive advantage in post-basic education in the Sultanate of Oman, Journal of Educational Sciences, Cairo University, 26 (2), 338-418.

Akbar, A. (2017), Administrative Leadership Practices to Achieve Competitive Advantage in Secondary Education Schools in Jeddah Governorate, Kingdom of Saudi Arabia, Ain Shams University, Journal of Scientific Research in Education, 18 (9), 373-414.

Akbar, Abeer (2017), Administrative leadership practices to achieve competitive advantage in secondary education schools in Jeddah, Saudi Arabia, Journal of Scientific Research in Education, 18 (9), 373-414.

Al-Ababneh, S. (2020), the Reality of the Competitive Advantage in Governmental Secondary Schools in the State of Kuwait from the Viewpoint of School Principals, The Jordanian Education Journal, 5 (2), 21-41.

Al-Ajmi, Muhammad (2020), The Reality of Competitive Advantage in Governmental Secondary Schools in the State of Kuwait from the Point of View of School Principals, The Jordanian Educational Journal, 5 (2), 21 41.

Al-Dhafiri, Mansour (2019), Requirements for achieving competitiveness in pre-university education schools in the State of Kuwait, Culture Association for Development, 141 (20), 309-342.

Al-Eid, Z. (2018), Requirements for achieving competitive advantage in private schools in Riyadh, College of Education Journal, 72 (2), 527-573.

Al-Ghamdi, F. (2014). A future vision for planning and developing the career path to achieve competitive advantage in Saudi higher education institutions. Umm Al-Qura University, Kingdom of Saudi Arabia.

Al-Hawajzah, K. (2010), Study of the Relationship of Knowledge Capital Strategies to the Competitive Performance of Institutions, University of Sharjah, Journal of Humanities and Social Sciences, 7 (2), 298311.

Al-Issawi, Muhammad (2018), The Impact of Strategic Vigilance in Achieving a Sustainable Competitive Advantage by Depending on the Results of the SWOT Environmental Analysis as an Interactive Variable: An Analytical Study of the Views of Members of the Board of Directors of Private Schools in Basra Governorate, Journal of Administrative Studies, 10 (20), 302-332. 
Al-Meligy, R. (2012), Management of Institutional Excellence between Theory and Practice, Oman: The World of Books.

Al-Salami, A. (2009), Strategic Human Resources Management, Cairo: Dar Gharib for Publishing and Printing.

Caldwell, C. (2017), Competitive Advantage : Strategies, Management and Performance, Hauppauge, New York : Nova Science Publishers, Inc. 2017. eBook., Database: eBook Collection (EBSCOhost).

Christensen, C. M., (2016). The Innovator's Dilemma: When New Technologies Cause Great Firms to Fail. Boston, MA: Harvard Business Review Press.

Dammaj, Amira (2019), The Role of Strategic Agility in Achieving Competitive Advantage in Secondary Schools in the Republic of Yemen, Al-Qalam Magazine, 12 (1), 341-369.

Egger, E. \& Hristova, S. (2018), Strategic Thinking And Management For A Competitive Advantage: Theoretical Perspectives On Family Businesses. Economic Development, 20(1),1/2, p257-271.

El-Sherbiny, A. (1984), the Need for New Directions for Arab Administrative Development Programs, Management News Journal, Arab Administrative Development Organization, 27 (1), 152-183.

El-Tayeb, D. (2007), Technological vigilance as a tool for building the competitive advantage of the economic institution, a study presented to the international forum (knowledge in the shadow of the digital economy), and its contribution to the formation of the competitive advantage of Arab countries, Chlef University publications, Algeria.

Khalil, Y. (2017), Strategic Leadership and Its Role in Improving the Competitive Advantage of Egyptian Universities, Ain Shams University, Journal of Scientific Research in Education, 8 (5), 128-183.

Khawaldeh, F. (2020), the Reality of Competitive Advantage in Governmental Secondary Schools in Mafraq Governorate: A Field Study on School Principals in Mafraq Governorate - Jordan, Journal of Educational and Psychological Sciences, 30 (4), 19-35.

Madhoun, M. (1999). The Impact of Implementing Total Quality Management on Gaining Competitiveness, An Applied Study on Jordanian Companies for the Chemical Organizations Industry. (unpublished Master Thesis). Al al-Bayt University, Jordan.

Masoud, Amal (2015), Strategic Features for Achieving the Competitive Advantage of Public Schools in Public Education in Egypt, Journal of the College of Education, 39 (3), 13-97.

Muhammad, M. (2020), Factors for Building Competitive Advantage in Educational Institutions, Journal of Scientific Research in Education, 21 (1), 149-169.

Porter, M. (2016). Advantage concurrencies of Nations, Inter Edition, New York Press.

Radwan, W. (2020), Leadership Skills as an Entrance to Achieving Competitive Advantage in Pre-University Education Institutions, The Educational Journal, 74 (1), 1129-1176.

Radwan, Wael (2020), Leadership Skills as an Entry to Achieve Competitive Advantage in Pre-University Education Institutions, The Educational Journal, 74 (1), 1129-1176.

Salah Al-Din, Nasreen (2018), Leadership practices in support of achieving a competitive advantage in basic education schools in the Governorate of Muscat, Sultanate of Oman, Journal of the College of Education in Educational Sciences, 42 (3), 234-314.

Salman, I. (2005), recent trends in marketing: the axis of performance in economic entities and mergers, Alexandria: Ma'arif facility.

Yassin, O. (2017), Electronic services in secondary schools in Gaza governorates and their relationship to the competitive advantage of the school, an unpublished master's thesis, Islamic University, Gaza. 